\title{
Transformation of Biomass Waste into Sustainable Organic Fertilizers
}

\author{
Kit Wayne Chew ${ }^{1, *(D)}$, Shir Reen Chia ${ }^{1}$, Hong-Wei Yen ${ }^{2} \mathbb{D}$, Saifuddin Nomanbhay ${ }^{3}$, \\ Yeek-Chia Ho ${ }^{4,5}$ and Pau Loke Show ${ }^{1, *(D)}$
}

1 Department of Chemical and Environmental Engineering, Faculty of Science and Engineering, University of Nottingham Malaysia, Jalan Broga, Semenyih 43500, Selangor Darul Ehsan, Malaysia; shireen.chia127@gmail.com

2 Department of Chemical and Materials Engineering, Tunghai University, Taichung 407, Taiwan; hwyen@thu.edu.tw

3 Institute of Sustainable Energy, Universiti Tenaga Nasional, Kajang 43000, Selangor, Malaysia; saifuddin@uniten.edu.my

4 Department of Civil and Environmental Engineering, Universiti Teknologi PETRONAS, Bandar Seri Iskandar 32610, Perak, Malaysia; yeekchia.ho@utp.edu.my

5 Centre for Urban Resource Sustainability, Institute of Self-Sustainable Building, Universiti Teknologi PETRONAS, Bandar Seri Iskandar 32610, Perak, Malaysia

* Correspondence: kitwayne.chew@gmail.com (K.W.C.); PauLoke.Show@nottingham.edu.my (P.L.S.); Tel.: +6-(03)-8924-8605 (P.L.S.)

Received: 30 March 2019; Accepted: 11 April 2019; Published: 15 April 2019

\begin{abstract}
The management of solid waste presents a challenge for developing countries as the generation of waste is increasing at a rapid and alarming rate. Much awareness towards the sustainability and technological advances for solid waste management has been implemented to reduce the generation of unnecessary waste. The recycling of this waste is being applied to produce valuable organic matter, which can be used as fertilizers or amendments to improve the soil structure. This review studies the sustainable transformation of various types of biomass waste such as animal manure, sewage sludge, municipal solid waste, and food waste, into organic fertilizers and their impact on waste minimization and agricultural enhancement. The side effects of these organic fertilizers towards the soil are evaluated as the characteristics of these fertilizers will differ depending on the types of waste used, in addition to the varying chemical composition of the organic fertilizers. This work will provide an insight to the potential management of biomass waste to be produced into organic fertilizer and the advantages of substituting chemical fertilizer with organic fertilizer derived from the biomass waste.
\end{abstract}

Keywords: biomass; organic fertilizer; plant growth; sustainability; waste

\section{Introduction}

A major issue presently is the increase in food demand due to rising populations, and this has created restrictions on land use for crops cultivation due to the need of these lands for industrialization and developments. Hence, to deliver the necessary food supplies, chemical fertilizers and pesticides have been applied extensively to increase the growth and yield of crops for food production. Fertilization is vital to improve the plant characteristics and uptake of nutrients. The addition of nitrogen fixation will enhance crop growth and avoid land degradation after long periods of agricultural activities. Phosphorus is crucial for energy metabolism, storage, and expression of genetic information [1]. On the other hand, potassium is essential for stimulating photosynthetic systems in plants and can improve plant growth, yield, and resistance to drought, thereby helping plants to maintain growth under 
stressed conditions [2]. However, the rigorous use of chemical fertilizers has led to the deterioration of the dynamic equilibrium of soil, flora and fauna ecosystems as well as water streams contamination. The need for sustainable fertilization with minimal environmental impact has given rise to the search for alternative fertilizer sources for use in agriculture [3]. This has generated increasing interest in renewable feedstock from biomass waste since the past decade.

The possibilities of these biomass waste sources as organic fertilizers have been evaluated by studying its effective management. Much of these biomass waste are disposed in landfills or incinerated due to the lack of space. The biomass waste contain valuable nutrients, which can be put to good use if managed properly. They contain high organic matter and can be treated to remove pathogens and then used to fertilize soils. Unlike chemical fertilizers, organic matter requires a period of time lag to mineralize. This mineralization time will depend on the composition of the organic matter, characteristics of soil, moisture, and temperature conditions [4]. The soil properties will also affect the chemical reactions in the soil and can alter the dynamics of the plant nutrients intake. Besides that, the feasibility of these organic fertilizers is largely dependent on the conversion processing costs, production costs, quality of the organic fertilizers, environmental assessments, and safety to human and animal health. The use of biofertilizers will also lead to the socioeconomic and ecological improvements, especially in soil quality amendments, which will contribute tremendously to the human health and safety, food quality, and environmental preservation [5].

The application of these organic fertilizers and soil amendments are very promising to increase food production and soil fertility while minimizing environmental damage [6]. Organic fertilization would improve crop yields and decrease the effects of groundwater contamination, which would otherwise be caused by using mineral fertilizers [7]. Furthermore, biofertilizers can also assists in the bioremediation of soils contaminated with pesticides and hydrocarbons. Hence, the recent challenge in agriculture research fields is to reduce the usage of high rates of chemical fertilizers, which will negatively affect human health and the environment [8]. With the preservation of the environment and waste reduction in mind, integrated nutrient management strategies such as the combination of chemical and organic fertilizers are being developed to enhance the sustainability of crop production.

This review summarizes various types of waste and their conversion into organic fertilizer for plant growth. The utilization of biowaste such as animal manure, sewage sludge, municipal solid waste, and food waste for biofertilizer and compost production were examined. Besides that, the advantages and drawbacks of using chemical and organic fertilizers were examined. Furthermore, the environmental assessments of biofertilizer, as well as the economic potential of biowaste conversion into biofertilizer were also discussed elaborately. This work will provide a comprehensive insight into the current progress in organic fertilizer production from biomass waste. This work also aims to provide insights on the development and transformation of waste into organic fertilizer to help reduce the impact to the environment.

\section{Utilization of Biowaste for Fertilizer Production and Plant Growth}

The use of chemical fertilizers containing mainly of nitrogen, phosphorus, and potassium (NPK) over the years have caused significant environmental impacts as these fertilizers have been applied widely over numerous lands across the world [9]. This calls for the need to recycle various types of biomass waste such as animal manure, sewage sludge waste, and food waste into organic fertilizers. Organic waste for utilization as agricultural fertilizers can be classified into several categories, namely: Animal-based organic waste (manure), compost (plant sources and food waste), and urban waste (sewage sludge and household waste) [10]. These wastes are processed to optimize their nutrients content and promote their agricultural value for the contribution to a more bio-friendly economy and environment. Table 1 shows the characteristic of different types of biowaste materials used for fertilizer production. There are many processing techniques to synthesis the organic fertilizers and the management of these biomass waste are essential to develop a sustainable cycle in terms of manageability, fertilizer value, soil amelioration value, as well as the environmental impacts [11]. 


\subsection{Animal Manure}

The application of animal manures as an optimal fertilizer for farming has been carried out across the globe for centuries. The increase in manures and excretions in farms are attributed to the elevating global population, which requires larger sources of food production. These manures are organic in nature and contain desirable nutrients like nitrogen and phosphorus, which can be used as fertilizers to produce high yield and good quality crop products. The management of these livestock excretions are necessary as they may show detrimental effects on long-term application on soil aggregation [7]. The nutrients from the excretions will accumulate on the surface of the soil and these nutrients will be washed into water streams by rainfall or surface runoff, causing the growth of algae and resulting in eutrophication [12]. Besides that, the livestock excretions are a major source of greenhouse gas (GHG) pollution, pathogens, and odour. Hence, appropriate manure management strategies such as the conversion to fertilizers of energy is essential to produce minimal effects to the environment while facilitating the efficient recycling of plant nutrients [13,14]. The benefits of applying manure as an organic fertilizer and concerns regarding the long-term use of these manures also need to be evaluated.

The utilization of livestock manure has showed promising results on enhancing plant growth (Table 1). Manure fertilizer applied on wheat has successfully improved the growth in terms of plant height, grain yield, and biological yield. The biological yield was increased by a rate of $15 \%$, attributed to the proper decay rate of manure that provides a good condition of steady nutrient release and soil texture amendments. Livestock manure used with chemical fertilizer such as nitrogen fertilizer showed no significant improvements as the livestock manure may have reduced its activity in the presence of nitrogen fertilizer [8]. Using effective microorganisms or biofertilizers for rice growth on farmyard amendments was also found to be better compared to NPK-fertilized soils after a three-month growth stage. The shoot biomass increased in all growth stages when biofertilizers were applied in the green manure amendment, while increase in the shoot biomass for farmyard manure amendment was observed at the final growth stage. As for the grain yield, biofertilizer use on NPK fertilizer amendment showed a $55 \%$ reduction in grain yield, whereas a $99 \%$ increase was obtained with green manure amendments, indicating the beneficial effects of these biofertilizers by combining the use of suitable soil amendment, particularly green manure amendments [15]. Another study on the growth response of coffee plant using organic manure showed significant proportional growth. Organic manure requires time to decompose and produce the desired nutrients. Thus, the integration of organic and inorganic fertilizer was found to yield comparable results to that of solely inorganic fertilizer. The combination of inorganic fertilizers, which can rapidly provide nutrients but lack balanced growth, and organic manure, which are slow to produce nutrients but can provide a good supply of nutrients, will lead to best proportional growth. This indicates that the use of integrated fertility management can encourage the use of organic manures to obtain efficient plant growth [16].

Furthermore, manure can retain the crop production for a longer period without the need for fresh fertilizer input. The growth of rice using chicken manure amendments sustained the productivity of the grain for the whole cropping cycle although much of the $\mathrm{N}$ and $\mathrm{K}$ contents were lost during the initial cropping stage, while organic $P$ from manure has benefited the plant growth in soils with reduced $P$ contents and high-phosphate adsorption capacity [17]. The renewable resource of animal manures has long been used as an organic fertilizer and contributes greatly in agricultural production. The application of sheep manure on contaminated soils was found to be very useful for phytostabilization, which is the plants' ability to stabilize pollutants in the soil. The uptake of $\mathrm{Pb}, \mathrm{Cd}$, and $\mathrm{Zn}$ by the plant tissues was reduced to an acceptable bioconcentration factor value as these manures can immobilize the metals in the contaminated soil, thereby reducing the metal toxicity and uptake by plants while having a low risk of groundwater leaching [18]. The use of solid pig and dairy manure could also improve the bacterial diversity throughout the growing season due to the nutritional resources in the manure that promote the bacterial growth in the soil ecosystem. The abundance of these good bacteria could contribute to plant health and decomposition of organic matter, by means of degrading complex substrates while consecutively producing antibiotics as a by-product. This shows potential of livestock 
manures to promote growth of bacterial communities for supporting plant productivity, pollutants degradation, and climate regulation [19].

The overuse of chemical $\mathrm{N}$ fertilizer has resulted in severe soil acidification, which is often associated with phosphorus deficiency, lower biodiversity, and productivity and aluminium toxicity [20]. Hence, the long-term use of animal manure has been evaluated for altering soil nitrogen immobilization to help with alleviating soil acidification. The study by Wang et al. (2019) reported that animal manure application gave a high stimulation effect on abiotic and biotic $\mathrm{N}$ immobilization, attributed to the increase in carbon availability and soil microbial activity at higher soil $\mathrm{pH}$ [21]. Nevertheless, the long-term animal manure application has shown to contribute towards soil aggregation. Macroaggregates are formed in soils with constant manure application and this affects the aggregate stability in soils [7]. Since salt content in animal feed are high in forage systems, the sodium ions originating from manure acts as a dispersing agent that reduces soil aggregate stability [22]. This also leads to the risk of soil salinization, especially in a humid region like south China [23]. However, in regions with constant rainfall, the aggregate stability is increased significantly as the soluble potassium and sodium ions can be easily leached under high rainfall conditions, where they accumulate less in those areas [7]. These nutrients will still be leached into the nearby water streams and are likely to cause groundwater pollution, which is a negative effect that needs to be considered.

\subsection{Sewage Sludge Waste}

Phosphorus is a key nutrient for all living beings, whereby its deficient in agriculture would compromise on crop productivity. The source of phosphorus is from non-renewable phosphate rocks, which is why there exists a need for efficient recycling of phosphorus compounds to ensure the capability of feeding a growing global population. Sewage sludge is one of the organic waste that contains a high concentration of phosphorus, in addition to other undesirable substances like heavy metals, pathogens, hydrocarbons, pharmaceuticals, and endocrine disruptors [24-26]. Sewage sludge has good agronomic properties with high nitrogen and phosphorus content, which can stimulate the soil microbial activity, soil enzymes activity, and soil respiration as a result of the degradation of organic matter [27]. However, sewage sludge also contains a variety of toxic contaminants, which poses a potential risk to the environment and human health. The beneficial fertilization using sewage sludge and the effects associated with its long-term application is further discussed.

Phosphorus fertilizer can be recovered from sewage sludge through various methods, for example, hydrothermal carbonization, pyrolysis, combustion, and composting (Table 1). The combination of hydrothermal carbonization, acidic leaching, and struvite precipitation was reported to reclaim a good portion (about $80 \%$ ) of the total phosphates. The acid acts as a catalyst to enhance the degree of carbonization as well as to increase the amount of ammonium available for struvite formation to elevate phosphate recovery [25]. On the other hand, the pyrolysis of sewage sludge can reduce the polycyclic aromatic hydrocarbons (PAHs) and toxic elements bio-accumulation in the sewage sludge. The resulting matter from pyrolysis will have a lowered sludge toxicity suitable for agricultural usage [28]. Besides that, composting is an effective and cost-efficient process to manage sewage sludge. Composting can biodegrade organic matter and produce substances that affect the mobility of heavy metals. The addition of phosphate amendments during sewage sludge composting also contributes to better fertilizer efficiency and heavy metals passivation, creating compost that are safe for agricultural applications [29].

The combustion of sewage sludge will produce ashes, which contain rich phosphorus content that are valuable as plant nutrients. Many treatment methods have been used to recover phosphorus from the sludge or increase the phosphate fraction in order to further utilize the sewage sludge ashes (SSA) as fertilizers, examples of the treatment processes are thermochemical treatment [30,31], acid or alkaline leaching [32], precipitation with lime water [33], and reaction with phosphoric acid [34]. The recovery of phosphorus from SSA through leaching can be further purified by the removal of heavy metals in SSA using ion exchange or sulphide precipitation. Most of the heavy metals present 
will form sparingly soluble sulphide compounds as the strong acid solutions can precipitate the stable heavy metal sulphide phases [33]. Figure 1 presents a process scheme to produce fertilizer from sewage sludge ash. The purification stage needs to be added if there is a high heavy metal content. The final product is in the form of precipitate or suspension fertilizers, as well as NP and PK fertilizers, which can be combined to form multicomponent NPK fertilizers [35]. The recycling of incinerated SSA is also a potential way to recover higher phosphate contents and utilize the remaining residual fractions. The availability of P compounds in the recycled fertilizer from SSA was comparable to that of commercial fertilizers. The phosphate uptakes using recycled phosphate fertilizers also showed higher rates as it released nutrients at a slow and consistent rate compared to that of commercial fertilizers [33]. Moreover, the utilization of low-temperature combustion can enrich the phosphorus content in SSA. Compared to pyrolysis and incineration, low-temperature combustion process was able to increase the total $\mathrm{P}$ content and bioavailable $\mathrm{P}$ content by about $45 \%$ and three times, respectively. This indicates the potentiality of low-temperature combustion as an alternative treatment for the enrichment and recycling of phosphorus from sewage sludge [36].

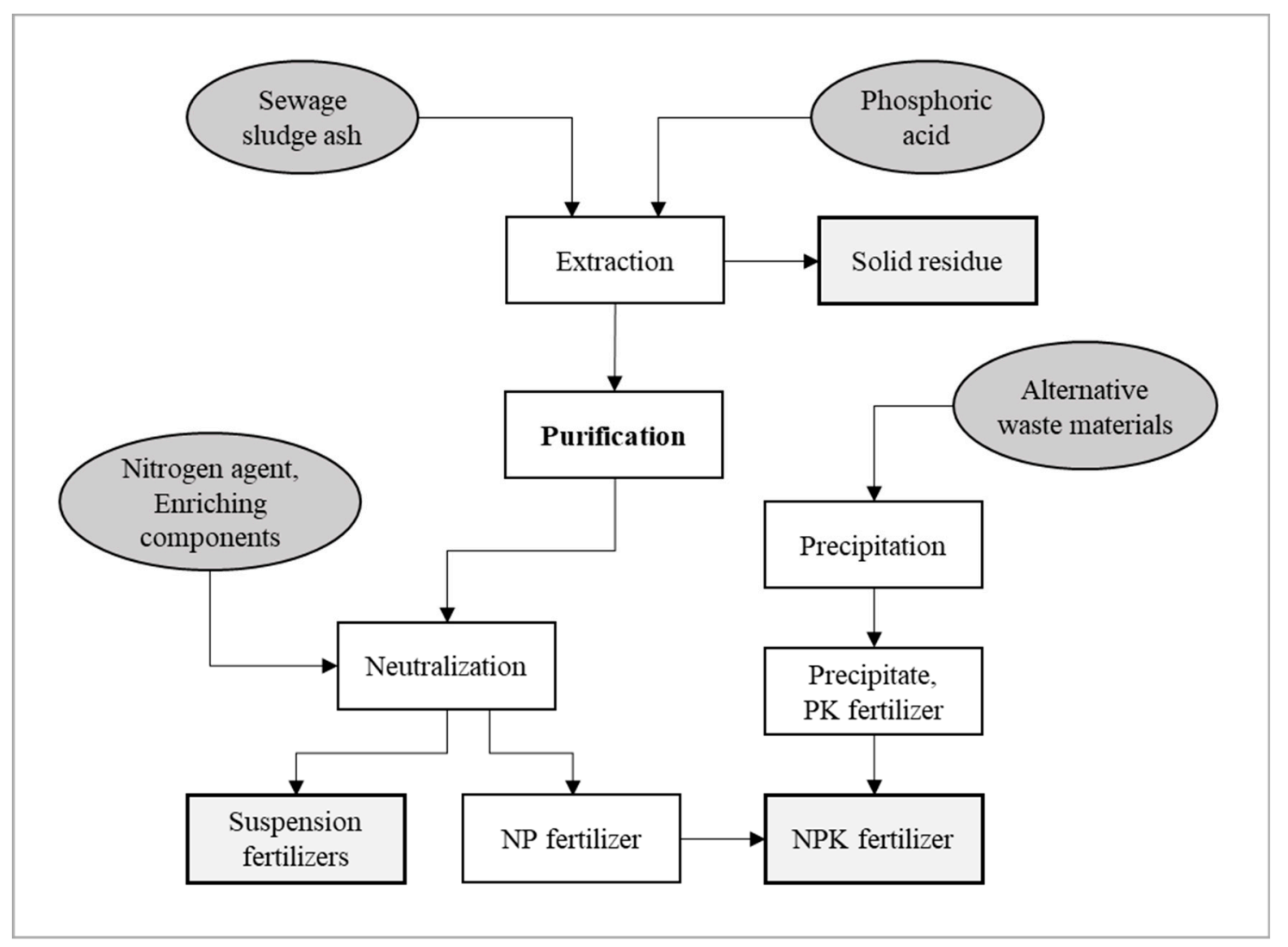

Figure 1. Process scheme of fertilizer production from sewage sludge ash (N: Nitrogen, P: Phosphorus, K: Potassium) [35].

The long-term application of sewage sludge was found to significantly increase the organic matter in soils. This causes soil $\mathrm{pH}$ reduction due to nitrification of ammonium contained in sewage sludge as well as the production of organic acids during the decomposition of organic matter [37]. Besides that, the long-term application was able to improve the physicochemical and microbial properties in agricultural soil but led to $\mathrm{Cu}$ and $\mathrm{Zn}$ accumulation in soil without improving their bioavailability [37].

\subsection{Food Waste Composting}

The increase in the global population has led to an increase in food consumption as well as food waste generation. Higher living standards in developed countries also contribute to the production of 
more food waste to meet the food quality demands. Much of the food waste generated from unused consumable food products, household food waste, and waste products from the food manufacturing and processing industries end up in landfills. Other treatment methods for food waste widely applied is animal feeding, anaerobic digestion, composting, and incineration [38]. The increasing food waste disposal has brought attention to the escalating issues in environmental pollution, which will bring harm to both humans and animals [39,40]. The decomposition of these organic waste in landfills will release compounds that create unpleasant odours, contaminate soil, and aquatic ecosystems, with the risk of diseases transmission to humans through contaminated materials. However, these organic food wastes can be converted into valuable organic matter through the implementation of microorganisms, which can naturally decompose the waste and transform them into usable compost. Food waste also contains high content of organic components such as carbohydrates, proteins, lipids, and organic acids, which makes it a potential source of fertilization [41].

Composting is a sustainable technique that converts these organic and biodegradable food waste into a stable form of organic matter and fertilizers that can be used for agriculture as soil amendments [42]. The content and quality of compost is dependent on the types of raw materials used, process of composting, conditions of decomposition process, and addition of nutrients during composting. The conversion of food and municipal solid waste to compost and its utilization for improving crop productivity and soil fertility will contribute to the soil organic matter management and reduction of the carbon footprint [43]. Nevertheless, there are several challenges in the composting process: (1) The process is lengthy and could take up to three to four months for a small-scale operation; (2) there may be acidification of soil and odour emissions during composting; (3) there are possibilities of heavy metals contamination; (4) the economic prospects of a composting facility is uncertain [39]. Hence, more effective and efficient methods of composting need to be developed to make the management of food waste through composting a promising direction for sustainability.

Compost has been used as fertilizers [44], organic amendments [45], for land reclamation [46], and many more agricultural applications (Table 1). The recycling of olive mill waste as an organic compost can enhance soil fertility as well as reduce the $\mathrm{CO}_{2}$ emissions. The agronomic performance of the olive mill waste compost were comparable to that of chemical fertilizer as it can supply adequate nutrients for plant growth, even for short-term crops [44]. Moreover, liquid fertilizer obtained through food composting can also be used to remediate contaminated soils. These liquid fertilizers have large amounts of organic matter content and are favoured for the preparation of dissolved organic carbon (DOC) solutions compared to wine-processing waste. DOC solutions are very useful in the adsorption of heavy metals such as $\mathrm{Zn}, \mathrm{Cu}$, and $\mathrm{Pb}$ in soils. The use of liquid fertilizer from composting processes was more efficient in reclaiming zinc-contaminated soil and the resulting fertility index were found to significantly increase as well, making it more favourable than the conventional use of acidic aqueous solutions [46]. Compost added with biochar has also produced positive results in continuous watermelon monocropping system. The combination of biochar with compost showed better watermelon yield due to the potentially reduced nutrients leaching and increased nutrient holding capacity of the soil [47].

The process of composting can also be improved by pelletizing the compost material. The in-farm pelletizing of swine manure solid fractions co-composted with organic waste materials showed comparable properties with commercial pelletized organic fertilizers [48]. The addition of co-formulates could lower moisture content and increase the pellet strength. This result shows the significance of co-composting of livestock manure to provide better sustainability and application in agriculture [48]. Besides that, a dynamic high-temperature aerobic fermentation (DHAF) process has also been developed for the rapid production of organic fertilizer from food waste. This process is conducted in a bioreactor where the rotation of the mixers will create intense collision and friction between the food waste particles. The food waste was subjected to continuous collision and friction, which creates a suitable environment for microorganisms to reproduce. The intense stirring segregated the food waste into smaller bits and the carbon dioxide produce through aerobic respiration of microorganisms was 
removed through the movement of food waste. The DHAF technique successfully converted food waste into mature organic fertilizer within 96 hours and this is attributed to the strong oxygen transfer and buffering capacity, as well as the high reaction surface area [49].

The long-term application of food waste compost was also reviewed to determine the effects of organic amendments to soil when applied for a long period. A study on the nitrogen availability after seven years of food waste compost application exhibited an increase in soil organic matter. The long-term value of compost for continuously supplying slow-release $\mathrm{N}$ for crops growth was apparent [50]. Moreover, long-term applications of compost were found to improve soil biological functions, for example, increasing the microbial biomass carbon. The long-lasting application of organic amendments also improved soil aggregate stability, enzymes activities, reduce soil bulk density, enhance soil organic nitrogen, and gave a positive effect in climate change mitigation by soil carbon sequestration [51,52]. These results indicate that the agronomic performance of compost-amended soil shows additional benefits to soil and will improve the crops yield and quality. The applications of organic-based agricultural fertilizer are very promising as it has the potential to convert biodegradable waste into valuable fertilizer products and should be considered as an effective management of compostable wastes.

\subsection{Vermicomposting}

Vermicomposting is a sustainable and economical process that involves the use of worms or wrigglers to convert organic waste materials into a nutrient rich and well stabilized material. Vermicompost is likened to peat and has excellent structure, aeration, porosity, and enhanced moisture holding capacity for promoting plant growth [53]. This type of composting requires a smaller area and the worms can hasten the breakdown of waste under suitable temperature conditions. Unlike typical composting, which requires the compost to be turned each week for aeration, vermicomposting consists of worms that will tunnel through the soil, creating air pathways to allow oxygen flow. Nonetheless, vermicomposting needs to be used in low temperature ranges to prevent the worms from dying [54]. The nurturing of earthworms in organic waste has the potential to transform wastewater sludge, food waste, animal waste, municipal waste, and other wastes into valuable fertilizer $[53,55,56]$. Besides that, the use of these organic fertilizers will maintain and improve the soil nutrients and soil structure (Table 1). 
Table 1. Characteristic of different types of biowaste materials used for fertilizer production.

\begin{tabular}{|c|c|c|c|c|}
\hline Types of Material & Source of Biomass & $\begin{array}{l}\text { Processing Treatment into } \\
\text { Fertilizer }\end{array}$ & Parameters Monitored and Their Resulting Effects & Reference \\
\hline Organic manure & Chicken manure, compost & Inoculation with Azotobacter & $\begin{array}{l}\text { Biological yield: Maximum rate achieved with the use of livestock manure. } \\
\text { Grain yield: Increase in biomass and plant height with good nutritional conditions } \\
\text { provided by organic manure. }\end{array}$ & [17] \\
\hline $\begin{array}{l}\text { Organic manure and green } \\
\text { manure }\end{array}$ & $\begin{array}{l}\text { Farmyard manure; Green } \\
\text { manure Trifolium alexandrianum }\end{array}$ & $\begin{array}{l}\text { Treatment with effective } \\
\text { microorganisms and fertilizer } \\
\text { solution }\end{array}$ & $\begin{array}{l}\text { Shoot biomass and grain yield: Enhanced rice shoot biomass and grain yield was observed } \\
\text { using green manure as soil amendments. }\end{array}$ & [15] \\
\hline Organic manure & Various livestock & Mixed with composted humus & $\begin{array}{l}\text { Soil fertility: Most significant proportional growth was obtained with organic manure. } \\
\text { Water level: Coffee plants grew better when lower irrigation water level is supplied. }\end{array}$ & [16] \\
\hline Organic manure & Sheep manure & Mixed with chemical fertilizer & $\begin{array}{l}\text { Accumulation of heavy metals: The uptakes of } \mathrm{PB}, \mathrm{Cd} \text {, and } \mathrm{Zn} \text { by plants were controlled } \\
\text { efficiently with the addition of sheep manure. }\end{array}$ & [18] \\
\hline Organic manure & $\begin{array}{l}\text { Solid pig manure, solid dairy } \\
\text { manure }\end{array}$ & $\begin{array}{l}\text { Surface applied and } \\
\text { incorporated using cultivator } \\
\text { implement }\end{array}$ & $\begin{array}{l}\text { Bacterial diversity: Manure amendments achieved greater bacterial diversity with longer } \\
\text { lasting effect compared to granular urea } \mathrm{N} \text { treatment. }\end{array}$ & [19] \\
\hline Animal manure & $\begin{array}{l}\text { Various livestock: chicken, pig } \\
\text { and pigeon }\end{array}$ & $\begin{array}{l}\text { Mixed with inorganic fertilizer } \\
\text { in field experiment }\end{array}$ & $\begin{array}{l}\text { Soil salinity: Increased in total soluble salts, decreased in } \mathrm{pH} \text { and occurrence of secondary } \\
\text { soil salinization. Heavy rainfall reduced the soil TSS concentration considerably. }\end{array}$ & [23] \\
\hline Animal manure & Pig or cattle manure & $\begin{array}{l}\text { Mixed with inorganic fertilizer } \\
\text { in field experiment }\end{array}$ & Aggregate stability: Decreased stability but increased the biological binding agent content. & [7] \\
\hline Animal manure & Pig and cattle manure & Mixed with inorganic fertilizer & $\begin{array}{l}\text { Soil aggregation: Increased risk of soil structure degradation due to high salt content. Can } \\
\text { be alleviated by straw incorporation. }\end{array}$ & [22] \\
\hline Sewage sludge ash & Wastewater treatment plant & $\begin{array}{l}\text { Acid leaching; ion exchange; } \\
\text { precipitation with lime water }\end{array}$ & $\begin{array}{l}\text { Phosphate uptake: A higher uptake rate was found compared to commercial fertilizer as } \\
\text { the high solubility of commercial fertilizers led to the rapid formation of insoluble } \\
\text { compound which prevented plant growth. Recycled phosphate has lower solubility and } \\
\text { was able to produce its effect over a longer period of time. }\end{array}$ & [33] \\
\hline Sewage sludge & - & $\begin{array}{l}\text { Thermally dried and } \\
\text { anaerobically digested }\end{array}$ & $\begin{array}{l}\text { Soil properties: Higher values of organic matter, total } \mathrm{K}, \mathrm{N} \text { and minerals. } \\
\text { Microbial properties: Higher microbial activities seen in sewage sludge amended soils. }\end{array}$ & {$[37]$} \\
\hline Sewage sludge & Wastewater treatment plant & $\begin{array}{l}\text { Hydrothermal carbonization, } \\
\text { acidic leaching and struvite } \\
\text { precipitation }\end{array}$ & $\begin{array}{l}\text { Phosphate recovery: High recovery rate of about } 80 \% \text {. Alternative acids can be used to save } \\
\text { material costs. }\end{array}$ & [25] \\
\hline $\begin{array}{l}\text { Municipal activated sewage } \\
\text { sludge; Industrial activated } \\
\text { sludge }\end{array}$ & Wastewater treatment plant & Pyrolysis process & $\begin{array}{l}\text { Element bioavailability: Pyrolyzed products contain better phosphorus pools for long-term } \\
\text { bioavailability. } \\
\text { Nutrient content: Increased nutrient content with pyrolysis and decreased PAH } \\
\text { concentrations and pollutant mobility. }\end{array}$ & {$[28]$} \\
\hline Dewatered fresh sewage sludge & $\begin{array}{l}\text { Municipal wastewater } \\
\text { treatment plant }\end{array}$ & Composting using reactor & $\begin{array}{l}\text { Composting process: Addition of phosphate amendments promoted temperature rise, } \\
\text { degradation of organic matter and higher nutrient control. }\end{array}$ & [29] \\
\hline Compost & Food waste and cattle manure & - & $\begin{array}{l}\text { Soil properties: Total } \mathrm{N} \text { and organic carbon level declined due to leaching and soil erosion. } \\
\text { Yield: higher maize yield observed with compost mix of } 50 \% \text { food waste with } 50 \% \text { cattle } \\
\text { manure. }\end{array}$ & [42] \\
\hline
\end{tabular}


Table 1. Cont.

\begin{tabular}{|c|c|c|c|c|}
\hline Types of Material & Source of Biomass & $\begin{array}{l}\text { Processing Treatment into } \\
\text { Fertilizer }\end{array}$ & Parameters Monitored and Their Resulting Effects & Reference \\
\hline Compost & Olive mill waste & $\begin{array}{l}\text { Mechanical turning and } \\
\text { watered to compensate } \\
\text { evaporation }\end{array}$ & $\begin{array}{l}\text { Agronomic: The yield of crops using compost was comparable to that of chemical fertilizers. } \\
\text { No significant difference was observed in humic content between compost and chemical } \\
\text { fertilizer. }\end{array}$ & [44] \\
\hline Compost-Liquid fertilizer & $\begin{array}{l}\text { Moisture from fermentation } \\
\text { process }\end{array}$ & Collection of moisture released & $\begin{array}{l}\text { Soil reclamation: Dissolved organic carbon solution prepared from food waste composting } \\
\text { removed about } 43 \% \text { and } 21 \% \text { of the initial } \mathrm{Zn} \text { from topsoil and subsoil during the soil } \\
\text { washing. }\end{array}$ & [46] \\
\hline Compost & Food waste: Rice, cabbage, pork & $\begin{array}{l}\text { Dynamic high-temperature } \\
\text { aerobic fermentation bioreactor }\end{array}$ & $\begin{array}{l}\text { Composting process: Stable } \mathrm{pH} \text { and electric conductivity value achieved after } 96 \mathrm{~h} \text { of } \\
\text { fermentation. Matured organic fertilizer obtained within } 96 \mathrm{~h} \text {. Continuous collision and } \\
\text { friction within bioreactor creates perfect environment for microorganisms to reproduce. }\end{array}$ & [49] \\
\hline Compost & Swine manure solid fraction & $\begin{array}{l}\text { Windrow composting; } \\
\text { pelletization }\end{array}$ & $\begin{array}{l}\text { Pellets formation: Comparable properties with commercial organic fertilizers. Potential } \\
\text { co-composting to improve livestock farming sustainability for agricultural uses. }\end{array}$ & [48] \\
\hline Vermicompost & $\begin{array}{l}\text { Cattle manure; Earthworms } \\
\text { (Eisenia fetida) }\end{array}$ & $\begin{array}{l}\text { Vermicomposted for two } \\
\text { months }\end{array}$ & $\begin{array}{l}\text { Vermicompost properties: Beneficial to soil structure and nutrient availability. } \\
\text { Yield: Increase in vegetative growth and yield of peppermint without negative effect on } \\
\text { human health and environment. }\end{array}$ & [57] \\
\hline Vermicompost & $\begin{array}{l}\text { Cow manure-solid waste, } \\
\text { sewage sludge; Earthworms } \\
\text { (Eisenia fetida) }\end{array}$ & $\begin{array}{l}\text { Combination of waste in } \\
\text { reactors }\end{array}$ & $\begin{array}{l}\text { Vermicompost properties: Reduced pathogens to achieve safe compost standard. } \\
\text { Microbial pathogens dynamics: Significant reduction in microbial pathogens achieved and } \\
\text { microbiological quality of class A compost attained. }\end{array}$ & {$[54]$} \\
\hline Vermicompost & $\begin{array}{l}\text { Wastewaster sludge; } \\
\text { Earthworms (Eisenia fetida) }\end{array}$ & $\begin{array}{l}\text { Aerobic digestion of wastewater } \\
\text { sludge, followed by } \\
\text { vermicomposting }\end{array}$ & $\begin{array}{l}\text { Vermicompost properties: Compost rich in nutrients and low in pathogens were produced. } \\
\text { Plant growth: Vermicompost stimulated plant growth better than sludge and limed sludge } \\
\text { amendments. Vermicompost treatment yielded plants with the highest weight and height. }\end{array}$ & {$[58]$} \\
\hline Vermicompost & $\begin{array}{l}\text { Cow dung, bakery industry } \\
\text { sludge; Earthworms } \\
\text { (Eisenia fetida) }\end{array}$ & $\begin{array}{l}\text { Left for decomposition and } \\
\text { vermicomposted for three } \\
\text { months }\end{array}$ & $\begin{array}{l}\text { Vermicomposting: Enriched nutrients (NPK) content compared to raw wastes. Potential } \\
\text { biotransformation of sludge waste to compost for soil health improvement. }\end{array}$ & [53] \\
\hline Vermicompost & $\begin{array}{l}\text { Municipal solid waste; } \\
\text { Earthworms (Eudrilus eugeniae) }\end{array}$ & Vermicomposted for 8 weeks & $\begin{array}{l}\text { Vermicomposting: High remediation capacity and useful for subsiding metalliferous soils } \\
\text { and reducing contaminants. Good management strategy for mitigating ecotoxicity in heavy } \\
\text { metals-contaminated soil. }\end{array}$ & {$[56]$} \\
\hline
\end{tabular}


Soil remediation by using vermicompost from municipal solid wastes showed that vermicompost was proficient in mitigating the heavy metals-contaminated soils, in addition to enhancing plant growth [56]. The use of cow manure vermicompost on peppermint growth reported that plants treated with vermicompost were the tallest and had the highest level of chlorophyll, carotenoids, and essential oil content. Better vegetative growth was observed in locations with low sunshine and moderate temperatures while higher oil yield and antioxidant capacity was observed in locations with high sunshine and high temperatures [57]. Valdez-Perez et al. (2011) researched on the vermicomposting of wastewater sludge to improve its nutrient content and reduce pathogenic content. The wastewater sludge was digested aerobically in a reactor with the addition of flocculants. The resulting biosolids was cultivated with Eisenia fetida to obtain the vermicompost with the best stability and maturity. The plants treated with vermicompost grew to be the tallest with the most leaves and heaviest, though the total $\mathrm{N}$ content was lower compared to limed biosolids [58]. This shows that vermicomposting of wastewater sludge could enrich the nutrients in the resulting compost and will contribute to the environment through the bioconversion of these wastes for fertilization [55].

The vermicompost derived from the mixture of cow manure, wastewater sludge, and municipal solid waste was also found to greatly reduce the number of microbial in the waste. Vermicompost is able to eliminate significant amounts of pathogens through factors such as worm gut enzymes, coelomic fluid secretion and competition between microorganisms [59]. Different treatments on the earthworm gut will also affect the microbial population differently. The earthworms consume the pathogens as food and their proteolytic enzymes activity will help to eliminate the pathogens, thereby promoting the use of earthworms to significantly reduce the pathogens to an acceptable microbiological quantity without the need for increased temperature [54]. Apart from that, the leachate from vermicompost has found to be useful as a liquid fertilizer after dilution with NPK fertilizers. These leachates contain a large amount of nutrient, high germination index, and is free of pathogens. Cow manure was composted thermophilically and the resulting compost was added with earthworms and left to vermicompost for two months. The leachate from the vermicompost bed was drained and collected for fertilizer usage. The humic acids and plant growth regulator components in the leachate increased the number of roots and stimulated the nutrient uptake for plant growth [60]. The improvements in physico-chemical properties make vermicompost an ideal amendment for field applications to improve soil health.

\section{Biofertilization in Agricultural Practices}

Biofertilizers are composed of agriculturally beneficial microorganisms that can improve the soil condition and plant growth through mobilizing the available nutrients with their biological activities. The microbes present secrete many health and nutrient enhancement compounds, which will promote the growth of plants [3]. These microorganisms also contribute in the life cycle of plants through the decomposition of organic matter, nitrogen fixation, and supply to plants as well as the solubilisation of insoluble phosphates. The biological fertilization provides benefits to soil and crops production, but this practice also has its limitations and its feasibility needs to be studied to evaluate its potential use in the future (Table 2). 
Table 2. Benefits and limitations of chemical and biological fertilizers [3,61-63].

\begin{tabular}{|c|c|c|}
\hline Type of Fertilizer & Benefits & Limitations \\
\hline Chemical fertilizer & $\begin{array}{l}\text { - Nutrients are readily available to } \\
\text { the plants. } \\
\text { - } \quad \text { Efficiency of nutrients placement is } \\
\text { immediate and direct. } \\
\text { - } \quad \text { Lower cost compared to organic fertilizer. } \\
\text { - } \quad \text { High in nutrient content and is needed } \\
\text { only in small amounts for adequate } \\
\text { crops growth. }\end{array}$ & 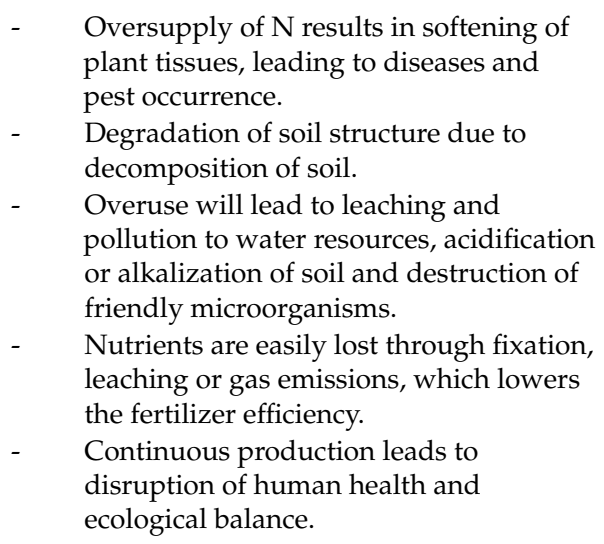 \\
\hline Biofertilizer & 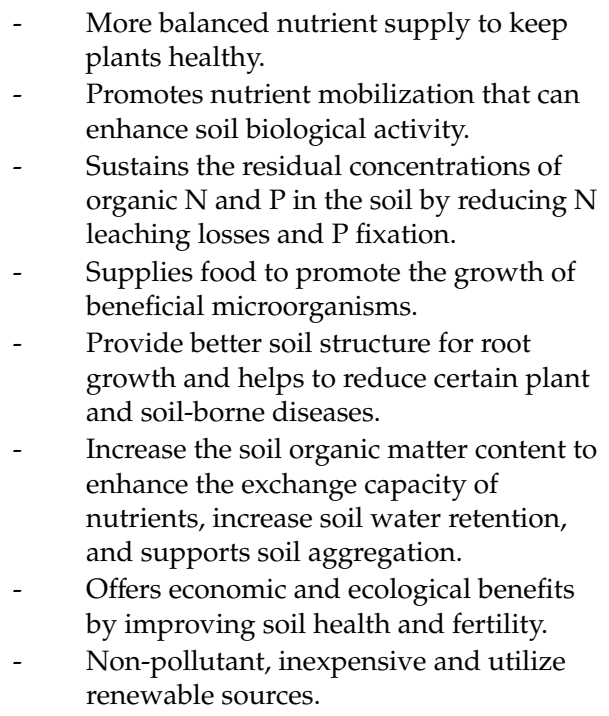 & $\begin{array}{l}\text { Low in nutrient content and is needed in } \\
\text { large volumes to sustain crops growth. } \\
\text { Composition of compost is variable and } \\
\text { might not contain the necessary major } \\
\text { nutrients for crops growth. } \\
\text { Nutritional deficiencies could occur due } \\
\text { to the slow transfer rate of micro- } \\
\text { and macro-nutrients. } \\
\text { Extensive application and long-term } \\
\text { usage may result in accumulation of salts, } \\
\text { nutrients, and heavy metals, which will } \\
\text { affect plant growth, human health, water } \\
\text { quality, and soil organisms. }\end{array}$ \\
\hline
\end{tabular}

The use of organic and chemical fertilizer combination has shown remarkable improvements on crop yields and soil organic carbon. Despite the ability of NPK fertilizers to rapidly enhance crop growth in the initial stage, the use of organic fertilizers will contribute to the overall plant growth and soil organic carbon content in the long run [64]. The combination of organic and chemical fertilizers also achieve comparable productivity to that of conventional $\mathrm{N}$ and $\mathrm{P}$ sources, and at the same time, decreasing the loss of nutrients through the use of organic materials [65]. Besides that, the inclusion of organic amendments will improve the environmental benefits as most of these biofertilizers are derived from waste. This will create a sustainable and efficient fertilization process in the long term, while simultaneously mitigating environmental pollution. It is essential that a balanced nutrition with adequate $\mathrm{N}$ and other nutrients are provided to crops to obtain high yield and good quality products [66]. Apart from that, it is well known that biofertilizers have notable characteristics for improving soil biological fertility and suppressing soil-borne pathogens. The long-term application of chemical fertilizers will eventually lead to the decrease in bacterial community within the soil. Hence, biofertilizers will assist in regulating the soil biological properties and strengthen the microbial community structure to produce healthy soil microbials [63]. Biofertilizer with chemical fertilizer combination is also a promising approach to preserve the soil microbiota balance in a continuous 
cycle of cropping cultivation, which is attributed to the beneficial bacteria encapsulation ability of biofertilizer that helps to regulate the functional bacteria in the crop fields [64].

\section{Environmental Impact of Fertilizers and Biofertilizers}

Various types of biofertilizers have been developed due to their potential as a more environmentally friendly, economical and sustainable alternative to inorganic fertilizers. Biofertilizers play an important role in the sustainability of the soil fertility as well as on plant productivity. For example, mycorrhiza, a type of fungi found widely in soils, can assists in the phosphorus intake of plants, improve resistance to root pathogens, and increase the tolerance of plants to environmental and biological stress. This fungal system has the capability to extend into a wide area for nutrients extraction and to withstand unfavourable conditions [67]. Furthermore, the macroalgal biorefinery for integrated production of fuel, biomolecules, and fertilizers can contribute to environmental restoration and climate mitigation. This is seen through the cultivation of seaweed, which can act as a biofilter as these seaweeds will extract excess nitrogen, phosphorus, carbon dioxide, and heavy metals pollutants from the aquatic system during the harvesting process. Hence, this will lead to cleaner and safer water sources for human health and the environment [68].

The composting process would contribute in the sustainable management of organic waste as these wastes can be reused as valuable sources of fertilizer [69]. Composting is simple and quick to implement, in addition to its lower environmental and social costs, compared to other organic waste disposal methods such as landfilling and incineration. It also allows the good management of waste streams, reduces organic matter quantity to landfills, and lowers greenhouse gas emissions. Studies have shown that it is a feasible strategy to convert these waste into compost with a high fertilizer value [70-72]. The use of compost amendments and green manure can also reduce the soil $\mathrm{N}_{2} \mathrm{O}$ emissions without increasing the $\mathrm{CO}_{2}$ emissions. A study on the use of green manure for mitigating soil GHG emissions in an irrigated maize production systems reported a $28 \%$ reduction in $\mathrm{N}_{2} \mathrm{O}$ fluxes and global warming potential [71].

The life cycle analysis (LCA) of fertilizer production is vital to create plans to counter and reduce the impacts to the environment. Table 3 shows the life cycle assessment categories that exist in a fertilizer production process. These categories include land use, greenhouse effect, climate change, human toxicity, acidification, eutrophication, and fossil fuel depletion. A life cycle analysis on two types of composting scale, home and industrial composting was carried out by Martinez-Blanco et al. (2010). It was discovered that industrial composting system would require more energy as there will be large amounts of biowaste transportation requirements. The waste generation and volatile organic compounds (VOCs) emissions from industrial composting are much higher, though the emissions of gases like $\mathrm{NH}_{3}, \mathrm{~N}_{2} \mathrm{O}$, and $\mathrm{CH}_{4}$ are lower compared to home composting. This is due to the biofiltration processes available in industrial processes to filter the exhaust gases [73]. Overall, the industrial composting was found to be more impacting in terms of ozone layer depletion potential, photochemical oxidation potential, and cumulative energy demand, where developments of the biofiltration processes of VOCs and energy minimization techniques should be explored to reduce the environmental impact of the system [73]. A life cycle GHG evaluation was also conducted for the organic rice production using organic fertilizers instead of chemical fertilizers. The practice of flooding the rice fields during cultivation leads to anaerobic conditions, which promote the generation and release of methane gases. The largest contributions to GHG emissions were from the field emissions compared to the planting, cultivating, and transporting process. By using organic fertilizers such as green manure seeds, farmyard manure, compost and biofermented juice derived from fermentation processes, the GHG emissions were found to be much lower $\left(0.58 \mathrm{~kg} \mathrm{CO}_{2}\right.$ per $\mathrm{kg}$ of paddy rice) compared to rice production with chemical fertilizer usage. The rice production practices can also be further adjusted by reducing the flooding period and applying alternative wetting and drying techniques to conserve water and mitigate methane emissions [74]. 
Table 3. Life cycle assessment categories for fertilizer production.

\begin{tabular}{lll}
\hline Category & Implications & References \\
\hline Land use & Land use efficiency increases with the fertilization intensity. & [75] \\
\hline Greenhouse effect & $\begin{array}{l}\text { Global warming potential can be reduced by the efficient } \\
\text { utilization of resources and minimizing of natural ecosystems } \\
\text { alteration. }\end{array}$ & [76] \\
\hline Climate change & $\begin{array}{l}\text { Selection of appropriate ingredients in the fertilizer product type } \\
\text { will significantly reduce emissions to the air. }\end{array}$ & [77] \\
\hline Human toxicity & $\begin{array}{l}\text { Zinc and arsenic are the main contributors to health impact. } \\
\text { Remediation of the marine system by bio-extraction can reduce } \\
\text { the impacts to human health. }\end{array}$ & [68] \\
\hline Acidification & $\begin{array}{l}\text { Acidification potential increases with nitrogen applications due to } \\
\text { ammonia volatilization. }\end{array}$ & [78] \\
\hline Eutrophication & $\begin{array}{l}\text { Eutrophication potential pattern changes with increase nitrogen } \\
\text { fertilizers usage. }\end{array}$ & [79] \\
\hline Fossil fuel depletion & $\begin{array}{l}\text { Utilization of biogas from non-food materials, e.g., organic } \\
\text { manure and maize silage, will lower the demand for fossil fuels } \\
\text { for fertilizer production. }\end{array}$ & [80] \\
\hline
\end{tabular}

\section{Economic Potential of Biowaste Conversion to Fertilizer}

An economic analysis revealed that the energy input of chemical fertilizers consists of the biggest share within the total energy inputs, owing to the inefficient usage of the fertilizer such that farmers tend to use more fertilizers than needed [81]. To overcome the environmental and health problems associated with the excessive use of these chemicals, the effective management of energy and resources for agricultural production must be applied. This will result in minimization of environmental impacts, preservation of natural resources and reduction of waste. One of the major environmental concerns is due to wastewater production and its adverse effect to the ecosystem when discharged to rivers, soils, or seas. The amount of communal and industrial sludge disposed at landfills has increased with the modern lifestyle and urbanization across the globe. Some of these wastewater sludges contain organic materials like bacteria, moulds, nutrients, and other molecules, which show potential for it to be used as fertilizers [11]. Economic studies were conducted on the recovery of struvite, a slow-releasing and high quality fertilizer, from wastewater [10,82]. The economical components, which include full scale fertilizer facility, struvite sale price, operating cost, net revenue, and many more were considered. The results after optimizing the experimental conditions found that the process is feasible with a relatively short payback time period of six years. There was also high potential to gain profits of twice its original investment as the price of struvite can be higher based on its applications such as boutique fertilizer [82].

Another study on the production of fertilizers from raw wastewater sludge experienced challenges in the removal of unwanted compounds like heavy metals and drying of the sludge, where the optimum process for rapid evaporation of unbound water molecules was essential [11]. The developed economical solution for processing sludge waste involves the drying of sludge in low vacuum, minimizing its volume, energy consumption, storage needs, and transportation costs. Chitosan magnetite nanoparticles were used to remove the heavy metals, and the recycling of these nanoparticles are essential to justify the economic potential for industrial processing. Furthermore, the costs of drying can be reduced by using the biogas produced through bio-fermentation of the sewage sludge. From the economic perspective, these findings can promote the feasibility of wastewater recycling for fertilizers production, which contributes to the sustainable waste management [83]. Figure 2 shows an energy self-sustainable sludge processing system for the treatment of sludge to fertilizers. The energy produced by the sludge in the wastewater can be utilized in various combinations, for example, the biogas obtained from anaerobic fermentation can be used to power the sludge processing system. The 
final dry sludge can be used for fertilizing agricultural and non-agricultural fields as well as incinerated to become fuel [11].

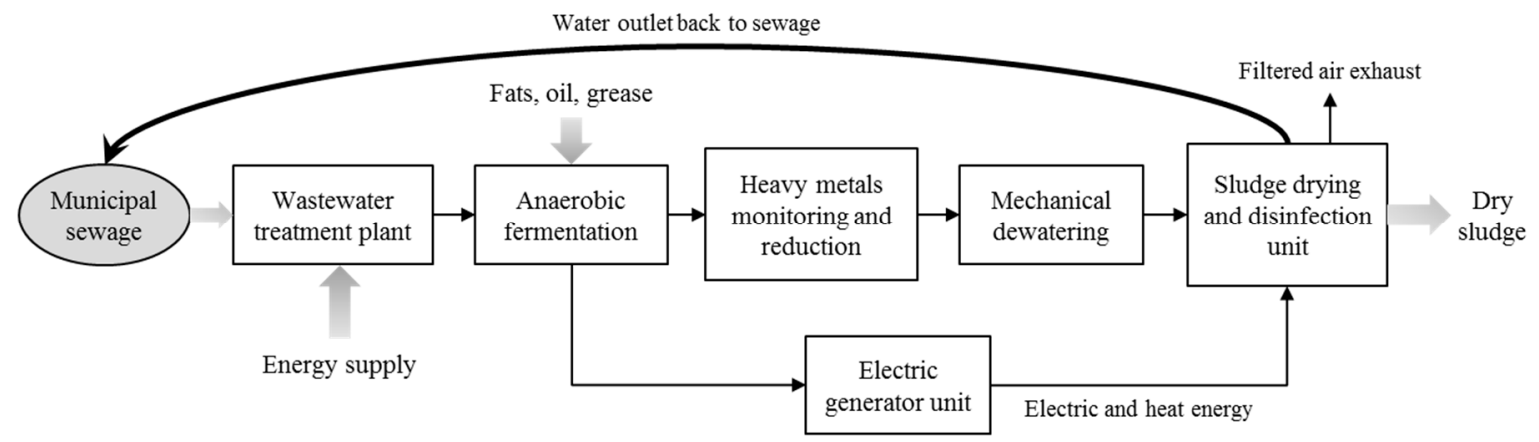

Figure 2. Energy self-sustainable sewage sludge processing system [11].

A field experiment conducted on fodder maize by altering the use of chemical, organic, and biofertilizer reported that the use of half fertilizer portion containing green compost and biofertilizer yielded the lowest expense [84]. Although higher biomass production was obtained from chemical fertilizer, the highest net profit was seen in the usage of biofertilizer with effective microorganisms or biological potassium fertilizer. NPK fertilizers produce rapid effects and they can achieve high yield in a short time, but biofertilizers are renewable and their effects last for a longer period with many additional benefits for plant growth [85]. The conversion of municipal solid waste into compost for seedling production was also found to have good economic potential. The substitution of peat with compost could reduce the cost of the substrates by up to $23 \%$. This reduction could generate an increment of $2.9 \%$ in the business contribution margin for crops productions. Supply of compost is in abundance and stable as it is obtained as a by-product generated from solid waste, enabling the transformation of the compost to value-added fertilizers to be sold at a secure price [70]. Hence, composting contributes tremendously in the efficient management of waste resources as well as adds economic value to waste by recycling the nutrient content and substrate components in the waste. Better economic prospects can be attained with the combination of bio and organic fertilizers together with chemical fertilizers to promote a sustainable crop production technology [84]. Owing to that, there is great economic potential in biowaste conversion, which can lead to a reduction in average costs of the growing media used for crops growth.

\section{Conclusions}

Growing concerns on environmental and ecological impacts associated with agriculture activities have created the need for more sustainable agriculture practices. Biological fertilizers derived from biowaste are studied for its potential as an alternative source of fertilization. The prospective of commercializing the production of biofertilizer requires useful information of the economic viability and potential environmental impacts, including the life cycle assessment of organic fertilizer production. The significant barriers in using organic fertilizer are most likely the uncertainties in nutrient content and suitability of utilization in soil. The agronomic yield of organic fertilizer may also be lower compared to the conventional mineral fertilizer management, though it will contribute towards a greener environment through GHG mitigation. There is a need to carefully examine the trade-offs between the synthetic $\mathrm{N}$ input in soil, crop yield and quality, economic feasibility, as well as the GHG emissions for protecting the environment.

The raw materials for biofertilizers are derived from biomass waste, and can be obtained for no cost with a reliable supply as these wastes are constantly being generated. With a higher demand of biofertilizers, the cost for biofertilizer will eventually reduce as the higher production rate will ease the production cost. The management and transformation of biomass waste into fertilizers has shown great advantages to soil and plant growth, besides contributing tremendously to the reduction 
of carbon footprint. It is vital to develop more efficient management processes to fully utilize the valuable compounds that can be extracted from these biomass waste and realize the commercialization of bio-products from biowaste.

Author Contributions: Conceptualisation-K.W.C. and P.L.S.; writing—original draft preparation, K.W.C., S.R.C., and P.L.S.; writing - review and editing, K.W.C., H.-W.Y., S.N., and Y.-C.H.; supervision, P.L.S.; funding acquisition, P.L.S., H.-W.Y., and S.N.

Funding: This study is supported by the Fundamental Research Grant Scheme (Malaysia, FRGS/1/2015/SG05/UNIM/03/1), the Ministry of Science and Technology (MOSTI02-02-12-SF0256) and the Prototype Research Grant Scheme (Malaysia, PRGS/2/2015/SG05/UNIM/03/1). A note of appreciation to iRMC UNITEN for the financial support through publication fund BOLD 2025 (RJO10436494).

Conflicts of Interest: The authors declare no conflict of interest.

\section{References}

1. Krüger, O.; Adam, C. Phosphorus in recycling fertilizers-analytical challenges. Environ. Res. 2017, 155, 353-358. [CrossRef] [PubMed]

2. Zahoor, R.; Dong, H.; Abid, M.; Zhao, W.; Wang, Y.; Zhou, Z. Potassium fertilizer improves drought stress alleviation potential in cotton by enhancing photosynthesis and carbohydrate metabolism. Environ. Exp. Bot. 2017, 137, 73-83. [CrossRef]

3. Bhardwaj, D.; Ansari, M.W.; Sahoo, R.K.; Tuteja, N. Biofertilizers function as key player in sustainable agriculture by improving soil fertility, plant tolerance and crop productivity. Microb. Cell. Fact. 2014, 13, 66. [CrossRef]

4. Tejada, M.; Gómez, I.; Fernández-Boy, E.; Díaz, M.-J. Effects of sewage sludge and Acacia dealbata composts on soil biochemical and chemical properties. Commun. Soil Sci. Plant Anal. 2014, 45, 570-580. [CrossRef]

5. Alfa, M.; Adie, D.; Igboro, S.; Oranusi, U.; Dahunsi, S.; Akali, D. Assessment of biofertilizer quality and health implications of anaerobic digestion effluent of cow dung and chicken droppings. Renew. Energy 2014, 63, 681-686. [CrossRef]

6. Silva, W.O.; Stamford, N.P.; Silva, E.V.; Santos, C.E.; Freitas, A.D.S.; Silva, M.V. The impact of biofertilizers with diazotrophic bacteria and fungi chitosan on melon characteristics and nutrient uptake as an alternative for conventional fertilizers. Sci. Hortic. 2016, 209, 236-240. [CrossRef]

7. Guo, Z.; Zhang, J.; Fan, J.; Yang, X.; Yi, Y.; Han, X.; Wang, D.; Zhu, P.; Peng, X. Does animal manure application improve soil aggregation? Insights from nine long-term fertilization experiments. Sci. Total Environ. 2019, 660, 1029-1037. [CrossRef]

8. Esmailpour, A.; Hassanzadehdelouei, M.; Madani, A. Impact of Livestock Manure, Nitrogen and Biofertilizer (Azotobacter) on Yield and Yield Components Wheat (Triticum Aestivum L.). Agron. Res. Mold. 2013, 46, 5-15. [CrossRef]

9. Savci, S. An agricultural pollutant: Chemical fertilizer. Int. J. Environ. Sci. Dev. 2012, 3, 73. [CrossRef]

10. Uysal, A.; Demir, S.; Sayilgan, E.; Eraslan, F.; Kucukyumuk, Z. Optimization of struvite fertilizer formation from baker's yeast wastewater: Growth and nutrition of maize and tomato plants. Environ. Sci. Pollut. Res. 2014, 21, 3264-3274. [CrossRef]

11. Bratina, B.; Šorgo, A.; Kramberger, J.; Ajdnik, U.; Zemljič, L.F.; Ekart, J.; Šafarič, R. From municipal/industrial wastewater sludge and FOG to fertilizer: A proposal for economic sustainable sludge management. J. Environ. Manag. 2016, 183, 1009-1025. [CrossRef] [PubMed]

12. Lee, Y.; Oa, S.-W. Nutrient transport characteristics of livestock manure in a farmland. Int. J. Recycl. Org. Waste Agric. 2013, 2, 1. [CrossRef]

13. Roubík, H.; Mazancová, J.; Banout, J. Current approach to manure management for small-scale Southeast Asian farmers-Using Vietnamese biogas and non-biogas farms as an example. Renew. Energy 2018, 115, 362-370. [CrossRef]

14. Sharara, M.; Sadaka, S. Opportunities and Barriers to Bioenergy Conversion Techniques and Their Potential Implementation on Swine Manure. Energies 2018, 11, 957. [CrossRef]

15. Javaid, A. Effects of biofertilizers combined with different soil amendments on potted rice plants. Chil. J. Agric. Res. 2011, 71, 157. [CrossRef] 
16. Chemura, A. The growth response of coffee (Coffea arabica L) plants to organic manure, inorganic fertilizers and integrated soil fertility management under different irrigation water supply levels. Int. J. Recycl. Org. Waste Agric. 2014, 3, 1-9. [CrossRef]

17. Steiner, C.; Teixeira, W.G.; Lehmann, J.; Nehls, T.; de Macêdo, J.L.V.; Blum, W.E.; Zech, W. Long term effects of manure, charcoal and mineral fertilization on crop production and fertility on a highly weathered Central Amazonian upland soil. Plant Soil 2007, 291, 275-290. [CrossRef]

18. Elouear, Z.; Bouhamed, F.; Boujelben, N.; Bouzid, J. Application of sheep manure and potassium fertilizer to contaminated soil and its effect on zinc, cadmium and lead accumulation by alfalfa plants. Sust. Environ. Res. 2016, 26, 131-135. [CrossRef]

19. Hamm, A.C.; Tenuta, M.; Krause, D.O.; Ominski, K.H.; Tkachuk, V.L.; Flaten, D.N. Bacterial communities of an agricultural soil amended with solid pig and dairy manures, and urea fertilizer. Appl. Soil Ecol. 2016, 103, 61-71. [CrossRef]

20. Zhou, J.; Xia, F.; Liu, X.; He, Y.; Xu, J.; Brookes, P.C. Effects of nitrogen fertilizer on the acidification of two typical acid soils in South China. J. Soil. Sedim. 2014, 14, 415-422. [CrossRef]

21. Wang, J.; Sun, N.; Xu, M.; Wang, S.; Zhang, J.; Cai, Z.; Cheng, Y. The influence of long-term animal manure and crop residue application on abiotic and biotic $\mathrm{N}$ immobilization in an acidified agricultural soil. Geoderma 2019, 337, 710-717. [CrossRef]

22. Guo, Z.; Zhang, Z.; Zhou, H.; Rahman, M.; Wang, D.; Guo, X.; Li, L.; Peng, X. Long-term animal manure application promoted biological binding agents but not soil aggregation in a Vertisol. Soil Tillage Res. 2018, 180, 232-237. [CrossRef]

23. Li-Xian, Y.; Guo-Liang, L.; Shi-Hua, T.; Gavin, S.; Zhao-Huan, H. Salinity of animal manure and potential risk of secondary soil salinization through successive manure application. Sci. Total Environ. 2007, 383, 106-114. [CrossRef]

24. Haiba, E.; Nei, L.; Herodes, K.; Ivask, M.; Lillenberg, M. On the degradation of metformin and carbamazepine residues in sewage sludge compost. Agron. Res. 2018, 16, 696-707.

25. Becker, G.; Wüst, D.; Köhler, H.; Lautenbach, A.; Kruse, A. Novel approach of phosphate-reclamation as struvite from sewage sludge by utilising hydrothermal carbonization. J. Environ. Manag. 2019, 238, 119-125. [CrossRef]

26. Fijalkowski, K.; Rorat, A.; Grobelak, A.; Kacprzak, M.J. The presence of contaminations in sewage sludge-The current situation. J. Environ. Manag. 2017, 203, 1126-1136. [CrossRef]

27. Andriamananjara, A.; Rabeharisoa, L.; Prud'homme, L.; Morel, C. Drivers of plant-availability of phosphorus from thermally conditioned sewage sludge as assessed by isotopic labeling. Front. Nutr. 2016, 3, 19. [CrossRef]

28. Frišták, V.; Pipíška, M.; Soja, G. Pyrolysis treatment of sewage sludge: A promising way to produce phosphorus fertilizer. J. Clean. Prod. 2018, 172, 1772-1778. [CrossRef]

29. Wang, X.; Zheng, G.; Chen, T.; Shi, X.; Wang, Y.; Nie, E.; Liu, J. Effect of phosphate amendments on improving the fertilizer efficiency and reducing the mobility of heavy metals during sewage sludge composting. J. Environ. Manag. 2019, 235, 124-132. [CrossRef] [PubMed]

30. Mattenberger, H.; Fraissler, G.; Brunner, T.; Herk, P.; Hermann, L.; Obernberger, I. Sewage sludge ash to phosphorus fertiliser: Variables influencing heavy metal removal during thermochemical treatment. Waste Manag. 2008, 28, 2709-2722. [CrossRef] [PubMed]

31. Vogel, C.; Exner, R.M.; Adam, C. Heavy metal removal from sewage sludge ash by thermochemical treatment with polyvinylchloride. Environ. Sci. Technol. 2012, 47, 563-567. [CrossRef]

32. Petzet, S.; Peplinski, B.; Cornel, P. On wet chemical phosphorus recovery from sewage sludge ash by acidic or alkaline leaching and an optimized combination of both. Water Res. 2012, 46, 3769-3780. [CrossRef]

33. Franz, M. Phosphate fertilizer from sewage sludge ash (SSA). Waste Manag. 2008, 28, 1809-1818. [CrossRef]

34. Weigand, H.; Bertau, M.; Hübner, W.; Bohndick, F.; Bruckert, A. RecoPhos: Full-scale fertilizer production from sewage sludge ash. Waste Manag. 2013, 33, 540-544. [CrossRef]

35. Gorazda, K.; Tarko, B.; Wzorek, Z.; Kominko, H.; Nowak, A.K.; Kulczycka, J.; Henclik, A.; Smol, M. Fertilisers production from ashes after sewage sludge combustion-A strategy towards sustainable development. Environ. Res. 2017, 154, 171-180. [CrossRef]

36. Meng, X.; Huang, Q.; Gao, H.; Tay, K.; Yan, J. Improved utilization of phosphorous from sewage sludge (as Fertilizer) after treatment by Low-Temperature combustion. Waste Manag. 2018, 80, 349-358. [CrossRef] 
37. Urra, J.; Alkorta, I.; Mijangos, I.; Epelde, L.; Garbisu, C. Application of sewage sludge to agricultural soil increases the abundance of antibiotic resistance genes without altering the composition of prokaryotic communities. Sci. Total Environ. 2019, 647, 1410-1420. [CrossRef]

38. Thi, N.B.D.; Kumar, G.; Lin, C.-Y. An overview of food waste management in developing countries: Current status and future perspective. J. Environ. Manag. 2015, 157, 220-229. [CrossRef]

39. Li, Y.; Jin, Y.; Borrion, A.; Li, H. Current status of food waste generation and management in China. Bioresour. Technol. 2019, 273, 654-665. [CrossRef]

40. Chew, K.W.; Chia, S.R.; Yap, Y.J.; Ling, T.C.; Tao, Y.; Show, P.L. Densification of food waste compost: Effects of moisture content and dairy powder waste additives on pellet quality. Proc. Saf. Environ. Prot. 2018, 116, 780-786. [CrossRef]

41. Chew, K.W.; Chia, S.R.; Show, P.L.; Ling, T.C.; Arya, S.S.; Chang, J.-S. Food waste compost as an organic nutrient source for the cultivation of Chlorella vulgaris. Bioresour. Technol. 2018, 267, 356-362. [CrossRef] [PubMed]

42. Wolka, K.; Melaku, B. Exploring selected plant nutrient in compost prepared from food waste and cattle manure and its effect on soil properties and maize yield at Wondo Genet, Ethiopia. Environ. Syst. Res. 2015, 4,1-7. [CrossRef]

43. Razza, F.; D'Avino, L.; L'Abate, G.; Lazzeri, L. The role of compost in bio-waste management and circular economy. In Designing Sustainable Technologies, Products and Policies; Springer: Berlin, Germany, 2018; pp. 133-143.

44. Altieri, R.; Esposito, A. Evaluation of the fertilizing effect of olive mill waste compost in short-term crops. Int. Biodeterior. Biodegrad. 2010, 64, 124-128. [CrossRef]

45. Castán, E.; Satti, P.; González-Polo, M.; Iglesias, M.C.; Mazzarino, M.J. Managing the value of composts as organic amendments and fertilizers in sandy soils. Agric. Ecosyst. Environ. 2016, 224, 29-38. [CrossRef]

46. Chiang, P.-N.; Tong, O.-Y.; Chiou, C.-S.; Lin, Y.-A.; Wang, M.-K.; Liu, C.-C. Reclamation of zinc-contaminated soil using a dissolved organic carbon solution prepared using liquid fertilizer from food-waste composting. J. Hazard. Mater. 2016, 301, 100-105. [CrossRef] [PubMed]

47. Cao, Y.; Ma, Y.; Guo, D.; Wang, Q.; Wang, G. Chemical properties and microbial responses to biochar and compost amendments in the soil under continuous watermelon cropping. Plant Soil Environ. 2017, 63, 1-7.

48. Romano, E.; Brambilla, M.; Bisaglia, C.; Pampuro, N.; Pedretti, E.F.; Cavallo, E. Pelletization of composted swine manure solid fraction with different organic co-formulates: Effect of pellet physical properties on rotating spreader distribution patterns. Int. J. Recycl. Org. Waste Agric. 2014, 3, 101-111. [CrossRef]

49. Jiang, Y.; Ju, M.; Li, W.; Ren, Q.; Liu, L.; Chen, Y.; Yang, Q.; Hou, Q.; Liu, Y. Rapid production of organic fertilizer by dynamic high-temperature aerobic fermentation (DHAF) of food waste. Bioresour. Technol. 2015, 197, 7-14. [CrossRef] [PubMed]

50. Sullivan, D.; Bary, A.; Nartea, T.; Myrhe, E.; Cogger, C.; Fransen, S. Nitrogen availability seven years after a high-rate food waste compost application. Compost Sci. Util. 2003, 11, 265-275. [CrossRef]

51. Mazzon, M.; Cavani, L.; Margon, A.; Sorrenti, G.; Ciavatta, C.; Marzadori, C. Changes in soil phenol oxidase activities due to long-term application of compost and mineral $\mathrm{N}$ in a walnut orchard. Geoderma 2018, 316, 70-77. [CrossRef]

52. Diacono, M.; Montemurro, F. Long-term effects of organic amendments on soil fertility. In Sustainable Agriculture Volume 2; Springer: Berlin, Germany, 2011; pp. 761-786.

53. Yadav, A.; Garg, V. Biotransformation of bakery industry sludge into valuable product using vermicomposting. Bioresour. Technol. 2019, 274, 512-517. [CrossRef] [PubMed]

54. Karimi, H.; Mokhtari, M.; Salehi, F.; Sojoudi, S.; Ebrahimi, A. Changes in microbial pathogen dynamics during vermicomposting mixture of cow manure-organic solid waste and cow manure-sewage sludge. Int. J. Recycl. Org. Waste Agric. 2017, 6, 57-61. [CrossRef]

55. Mahaly, M.; Senthilkumar, A.K.; Arumugam, S.; Kaliyaperumal, C.; Karupannan, N. Vermicomposting of distillery sludge waste with tea leaf residues. Sust. Environ. Res. 2018, 28, 223-227. [CrossRef]

56. Soobhany, N. Remediation potential of metalliferous soil by using extracts of composts and vermicomposts from Municipal Solid Waste. Proc. Saf. Environ. Prot. 2018, 118, 285-295. [CrossRef]

57. Ayyobi, H.; Peyvast, G.-A. The effects of cow manure vermicompost and municipal solid waste compost on peppermint (Mentha piperita L.) in Torbat-e-Jam and Rasht regions of Iran. Int. J. Recycl. Org. Waste Agric. 2014, 3, 147-153. [CrossRef] 
58. Valdez-Perez, M.; Fernández-Luqueño, F.; Franco-Hernandez, O.; Cotera, L.F.; Dendooven, L. Cultivation of beans (Phaseolus vulgaris L.) in limed or unlimed wastewater sludge, vermicompost or inorganic amended soil. Sci. Hortic. 2011, 128, 380-387. [CrossRef]

59. Hait, S.; Tare, V. Vermistabilization of primary sewage sludge. Bioresour. Technol. 2011, 102, $2812-2820$. [CrossRef]

60. Gutiérrez-Miceli, F.A.; García-Gómez, R.C.; Rosales, R.R.; Abud-Archila, M.; Angela, O.L.M.; Cruz, M.J.G.; Dendooven, L. Formulation of a liquid fertilizer for sorghum (Sorghum bicolor (L.) Moench) using vermicompost leachate. Bioresour. Technol. 2008, 99, 6174-6180. [CrossRef]

61. Carvajal-Muñoz, J.; Carmona-Garcia, C. Benefits and limitations of biofertilization in agricultural practices. Livest. Res. Rural Dev. 2012, 24, 1-8.

62. Chen, J.-H. The combined use of chemical and organic fertilizers and/or biofertilizer for crop growth and soil fertility. In Proceedings of the International Workshop on Sustained Management of the soil-Rhizosphere System for Efficient Crop Production and Fertilizer Use, Bangkok, Thailand, 16-26 October 2016; p. 20.

63. Saeed, K.S.; Ahmed, S.A.; Hassan, I.A.; Ahmed, P.H. Effect of bio-fertilizer and chemical fertilizer on growth and yield in cucumber (Cucumis sativus) in green house condition. Pak. J. Biol. Sci. 2015, 18, 129-134.

64. Li, R.; Tao, R.; Ling, N.; Chu, G. Chemical, organic and bio-fertilizer management practices effect on soil physicochemical property and antagonistic bacteria abundance of a cotton field: Implications for soil biological quality. Soil Tillage Res. 2017, 167, 30-38. [CrossRef]

65. Redding, M.; Lewis, R.; Kearton, T.; Smith, O. Manure and sorbent fertilisers increase on-going nutrient availability relative to conventional fertilisers. Sci. Total Environ. 2016, 569, 927-936. [CrossRef]

66. Agegnehu, G.; Nelson, P.N.; Bird, M.I. The effects of biochar, compost and their mixture and nitrogen fertilizer on yield and nitrogen use efficiency of barley grown on a Nitisol in the highlands of Ethiopia. Sci. Total Environ. 2016, 569, 869-879. [CrossRef]

67. Tiwari, P.; Prakash, A.; Adholeya, A. Commercialization of arbuscular mycorrhizal biofertilizer. Fungal Biotechnol. Agric. Food Environ Appl. 2003, 21, 195-204.

68. Seghetta, M.; Hou, X.; Bastianoni, S.; Bjerre, A.-B.; Thomsen, M. Life cycle assessment of macroalgal biorefinery for the production of ethanol, proteins and fertilizers-A step towards a regenerative bioeconomy. J. Clean. Prod. 2016, 137, 1158-1169. [CrossRef]

69. Lalevic, B.; Sivcev, B.; Raicevic, V.; Vasic, Z.R.; Petrovic, N.; Milinkovic, M. Environmental impact of viticulture: Biofertilizer influence on pruning and wine waste. Bulg. J. Agric. Sci. 2013, 19, 1027-1032.

70. Jara-Samaniego, J.; Perez-Murcia, M.; Bustamante, M.; Pérez-Espinosa, A.; Paredes, C.; López, M.; Lopez-Lluch, D.; Gavilanes-Terán, I.; Moral, R. Composting as sustainable strategy for municipal solid waste management in the Chimborazo Region, Ecuador: Suitability of the obtained composts for seedling production. J. Clean. Prod. 2017, 141, 1349-1358. [CrossRef]

71. Forte, A.; Fagnano, M.; Fierro, A. Potential role of compost and green manure amendment to mitigate soil GHGs emissions in Mediterranean drip irrigated maize production systems. J. Environ. Manag. 2017, 192, 68-78. [CrossRef]

72. De Mendonça Costa, M.S.S.; Bernardi, F.H.; de Mendonça Costa, L.A.; Pereira, D.C.; Lorin, H.E.F.; Rozatti, M.A.T.; Carneiro, L.J. Composting as a cleaner strategy to broiler agro-industrial wastes: Selecting carbon source to optimize the process and improve the quality of the final compost. J. Clean. Prod. 2017, 142, 2084-2092. [CrossRef]

73. Martínez-Blanco, J.; Colón, J.; Gabarrell, X.; Font, X.; Sánchez, A.; Artola, A.; Rieradevall, J. The use of life cycle assessment for the comparison of biowaste composting at home and full scale. Waste Manag. 2010, 30, 983-994. [CrossRef]

74. Yodkhum, S.; Gheewala, S.H.; Sampattagul, S. Life cycle GHG evaluation of organic rice production in northern Thailand. J. Environ. Manag. 2017, 196, 217-223. [CrossRef] [PubMed]

75. Charles, R.; Jolliet, O.; Gaillard, G.; Pellet, D. Environmental analysis of intensity level in wheat crop production using life cycle assessment. Agric. Ecosyst. Environ. 2006, 113, 216-225. [CrossRef]

76. Brentrup, F.; Pallière, C. GHG emissions and energy efficiency in European nitrogen fertiliser production and use. In Proceedings of the International Fertiliser Society Conference, Cambridge, UK, 11 December 2008; pp. 1-25.

77. Hasler, K.; Bröring, S.; Omta, S.; Olfs, H.-W. Life cycle assessment (LCA) of different fertilizer product types. Eur. J. Agron. 2015, 69, 41-51. [CrossRef] 
78. Brentrup, F.; Lammel, J. LCA to Assess the Environmental Impact of Different Fertilisers and Agricultural Systems; International Fertiliser Society: Leek, UK, 2011.

79. Boye, J.I.; Arcand, Y. Green Technologies in Food Production and Processing; Springer Science \& Business Media: Berlin, Germany, 2012.

80. Ahlgren, S.; Bernesson, S.; Nordberg, Å.; Hansson, P.-A. Nitrogen fertiliser production based on biogas-energy input, environmental impact and land use. Bioresour. Technol. 2010, 101, 7181-7184. [CrossRef]

81. Erdal, G.; Esengün, K.; Erdal, H.; Gündüz, O. Energy use and economical analysis of sugar beet production in Tokat province of Turkey. Energy 2007, 32, 35-41. [CrossRef]

82. Yetilmezsoy, K.; Ilhan, F.; Kocak, E.; Akbin, H.M. Feasibility of struvite recovery process for fertilizer industry: A study of financial and economic analysis. J. Clean. Prod. 2017, 152, 88-102. [CrossRef]

83. Eriksson, O.; Bisaillon, M.; Haraldsson, M.; Sundberg, J. Enhancement of biogas production from food waste and sewage sludge-environmental and economic life cycle performance. J. Environ. Manag. 2016, 175, 33-39. [CrossRef]

84. Jilani, G.; Akram, A.; Ali, R.M.; Hafeez, F.Y.; Shamsi, I.H.; Chaudhry, A.N.; Chaudhry, A.G. Enhancing crop growth, nutrients availability, economics and beneficial rhizosphere microflora through organic and biofertilizers. Ann. Microbiol. 2007, 57, 177-184. [CrossRef]

85. Shen, Z.; Ruan, Y.; Wang, B.; Zhong, S.; Su, L.; Li, R.; Shen, Q. Effect of biofertilizer for suppressing Fusarium wilt disease of banana as well as enhancing microbial and chemical properties of soil under greenhouse trial. Appl. Soil Ecol. 2015, 93, 111-119. [CrossRef]

(C) 2019 by the authors. Licensee MDPI, Basel, Switzerland. This article is an open access article distributed under the terms and conditions of the Creative Commons Attribution (CC BY) license (http://creativecommons.org/licenses/by/4.0/). 